ŁUKASZ KuŁAGA*

Uniwersytet Kardynała Stefana Wyszyńskiego

\title{
UŻYWANIE DRONÓW W CELU ZWALCZANIA MIĘDZYNARODOWEGO TERRORYZMU W ŚWIETLE „IUS IN BELLO”
}

\section{WPROWADZENIE}

Wzrastająca praktyka używania zbrojnych bezzałogowych statków powietrznych (ZBSP) ${ }^{1} \mathrm{w}$ celu eliminacji osób podejrzanych o terroryzm przez niektóre państwa wzbudza szereg kontrowersji. Międzynarodowy Komitet Czerwonego Krzyża (MKCK) zwraca uwagę, że „odłączenie osoby, w szczególności poprzez odległość (fizyczną lub emocjonalną) od potencjalnego przeciwnika sprawia, że dokonywanie ataku jest łatwiejsze i bardziej podatne na nadużycia"2.

\footnotetext{
Wszelkie poglądy wyrażone w niniejszym artykule pochodzą wyłącznie od Autora i nie mogą być utożsamiane ze stanowiskiem instytucji, w których jest on zatrudniony.

1 Pojęcie bezzałogowych statków powietrznych jest pojęciem prawa polskiego. Art. 95 ust. 2 pkt. 5a ustawy z dn. 3 lipca 2002 r. - Prawo lotnicze (Dz.U. z 2012 r. poz. 933, ze zm.) wymaga od osób będących operatorami bezzałogowych statków powietrznych używanych w celach innych niż rekreacyjne lub sportowe świadectwa kwalifikacji. Potocznie Agencja lotnictwa cywilnego stosuje także pojęcie „drony”, który to termin będzie również wykorzystywany w artykule, por. http://www.ulc.gov.pl/pl/uav.

2 International Humanitarian Law and the challenges of contemporary armed conflicts, Report, Document prepared by the International Committee of the Red Cross,
} 
Wykorzystywanie ZBSP w konfliktach zbrojnych oraz poza konfliktem zbrojnym powoduje, że zagadnienie to wymaga analizy z perspektywy zarówno ius in bello (międzynarodowego prawa humanitarnego - MPH), jak i międzynarodowego prawa praw człowieka (MPPC). Równocześnie problematyka ta wpisuje się również $\mathrm{w}$ relacje prawa międzynarodowego do nowych technologii, w szczególności kwestii, czy dotychczasowe prawo międzynarodowe jest wystarczające, czy też konieczne jest przyjęcie nowych rozwiązań - ukierunkowanych na regulację stosowania nowych technologii na polu walki ${ }^{3}$. Waga tego zagadnienia jest tym większa, że wykorzystywanie dronów jest krokiem $\mathrm{w}$ procesie wprowadzenia do użycia w konflikcie zbrojnym całkowicie zautomatyzowanych broni ${ }^{4}$. Co ważne, istnieje zasadniczy konsensus,

Geneva 2011, 31 IC/11/5.1.2, s. 39; Report of the Special Rapporteur on extrajudicial, summary or arbitrary executions Christof Heyns, A/68/382, 13.8.2013 r., [dalej Heyns Report], pkt 16 i 18 . Zauważa się przy tym, że drony stanowią jedynie etap w procesie zmierzającym do wykorzystania na polu walki w pełni zautomatyzowanych systemów broni, por. również M. WAGNER, The Dehumanization of International Humanitarian Law: Legal, Ethical, and Political Implications of Autonomous Weapon Systems, «Vanderbilt Journal of Transnational Law» 47/2014, s. 1379; M. RADZIEJOwskA Remote and Autonomous: From Drones to "Killer Robots", «PISM Strategic file», 60.24/2014; por. „Używanie dronów sygnalizuje obszar wyłączenia dla prawa... [...] ani wojna, ani egzekwowanie prawa, tą nową formę przemocy najlepiej analizować jako formę high-tech reżimu zniknięcia. Państwa zawsze miały powody do eliminacji tych którzy stwarzają zagrożenie”, P. W. KAHN, Imagining Warfare, «European Journal of International Law» [dalej EJIL] 24.1/2013, s. 226.

3 M. Bucholc, Użycie bezzałogowych aparatów latających w sytuacji konfliktu zbrojnego. Wybrane aspekty z zakresu międzynarodowego prawa humanitarnego, «Polski Rocznik Praw Człowieka i Prawa Humanitarnego» 3/2012, s. 169-182.

4 Kwestie te są przedmiotem dyskusji w ramach MKCK, por. ICRC Expert Meeting on 'Autonomous weapon systems: technical, military, legal and humanitarian aspects', 26-28.3.2014 r., Report of 1 November 2014, por. https://www.icrc.org/en/document/ report-icrc-meeting-autonomous-weapon-systems-26-28-march-2014 oraz Konwencji o zakazie lub ograniczeniu użycia pewnych rodzajów broni konwencjonalnych, które mogą być uważane za powodujące nadmiernie cierpienie lub mające niekontrolowane CO? z 1980 r., por. Report of the 2014 informal Meeting of Experts on Lethal Autonomous Weapons Systems (LAWS), 11.6.2014 r., por. http://daccess-dds-ny.un.org/doc/UNDOC/ GEN/G14/048/96/PDF/G1404896.pdf?OpenElement, jak również Instytutu NZ ds. Badań nad Rozbrojeniem UNIDIR, por. Framing Discussions on the Weaponization 
że ZBSP nie wymagają przyjęcia nowych partykularnych norm prawnych dotyczących ich stosowania ${ }^{5}$. Równocześnie jednak kontrowersje dotyczące okoliczności ich stosowania w kontekście zwalczana międzynarodowego terroryzmu wpływają na zróżnicowaną terminologię w tym zakresie. Dla jednych są one przykładem „pozasądowych zabójstw” (ang. extra judicial killings) lub „ukierunkowanych zabójstw” (ang. targeted killings) ${ }^{6}$, dla drugich stanowią środek do „zdjęcia z pola walki” (ang. take off the battlefield $)^{7}$ żołnierzy wrogiej strony (określanych równocześnie jako terroryści), czy „selektywnej eliminacji”. W tym zakresie trafny jest pogląd B. Emmersona, że w wyrażeniu „ukierunkowane

of Increasingly Autonomous Technologies, UNIDIR 2014, por. http://www.unidir.org/ files/publications/pdfs/framing-discussions-on-the-weaponization-of-increasingly-autonomous-technologies-en-606.pdf oraz The Weaponization of Increasingly Autonomous Technologies: Considering Ethics and Social Values, UNIDIR 2015, por. http:// www.unidir.org/files/publications/pdfs/considering-ethics-and-social-values-en-624. pdf.; por. również N. Melzer, Human Rights Implications of the Usage of Drones and Unmanned Robots in Warfare, European Parliament, Directorate General for External Policies, Policy Department Study, Brussels 2013, s. 11-14.

5 "Law should not follow drones, drones should follow law”, tak Christoph Heyns, United Nations Special Rapporteur on extrajudicial, summary, or arbitrary executions, w wystąpieniu w trakcie Panel discussion on Drones - 28th Meeting 28th Regular Session of Human Rights Council, 22.9.2014 r., por. http://webtv.un.org/watch/ panel-discussion-on-drones-28th-meeting-28th-regular-session-of-human-rights-council/3798750531001\#full-text .

6 "A targeted killing is the intentional, premeditated and deliberate use of lethal force, by States or their agents acting under colour of law, or by an organized armed group in armed conflict, against a specific individual who is not in the physical custody of the perpetrator", Report of the Special Rapporteur on extrajudicial, summary or arbitrary executions, Philip Alston, Addendum, A/HRC/14/24/Add.6, 28 May 2010, [dalej Alston Report], pkt 1; Jerzy Kranz używa pojęcia „celowanych zabójstw”, J. Kranz, Między wojną a pokojem: świat współczesny wobec użycia siły zbrojnej, [w:] Świat współczesny wobec użycia siły zbrojnej-dylematy prawa i polityki, red. J. KRANZ, Warszawa 2009, s. 130.

7 President Obama's counterterrorism policy speech, National Defense University - Fort McNair, Washington, D.C., 23.5.2013 r

8 Międzynarodowe Prawo Humanitarne-Selektywna eliminacja i rozkaz wojskowy, IV, Gdynia 2013 - pojęcie to, jak zauważają zresztą sami autorzy artykułów zawartych $\mathrm{w}$ Tomie, jest eufemizmem. 
zabójstwa” (ang. targeted killings) „jego treść oraz znaczenie różni się w zależności od reżimu prawnego mającego zastosowanie w konkretnych okolicznościach faktycznych" .

Celem artykułu jest nakreślenie ogólnych ram prawnych dotyczących używania ZBSP w celu zwalczania terroryzmu z perspektywy $\mathrm{MPH}$ oraz MPPC. $\mathrm{Z}$ tego względu zasadniczo jego przedmiotem nie jest ocena prawna poszczególnych, konkretnych sytuacji, kiedy drony były stosowane. Równocześnie należy zastrzec, że w artykule nie zostaną przedstawione rozważania dotyczące definicji międzynarodowego terroryzmu oraz prawa do wojny (ius ad bellum). Obszerność tych zagadnień nie pozwala w ograniczonej formie, jaką jest artykuł naukowy, na szczegółowe przedstawienie tej problematyki ${ }^{10}$. W tym kontekście warto zaznaczyć jednak, że zgodność działań państwa z ius ad bellum, w przypadku używania dronów w celu zwalczania terroryzmu międzynarodowego nie oznacza, że posiada ono nieograniczoną swobodę w zakresie podejmowanych działań. W komentarzu do artykułu 21 dotyczącego samoobrony z Artykułów o odpowiedzialności państw Komisja Prawa Międzynarodowego stwierdziła „Nie oznacza to, że samoobrona wyłącza odpowiedzialność za zachowania we wszystkich przypadkach lub w odniesieniu do wszystkich zobowiązań." łowe powołanie się na prawo do samoobrony zatem pozwala państwu na uniknięcie odpowiedzialności prawnomiędzynarodowej za naruszenie zakazu użycia siły oraz ewentualnie, w przypadku konfliktu międzynarodowego, również suwerenności terytorialnej oraz zasady nieinterwencji w sprawy wewnętrzne państw. Nie zwalnia jednakże ono państwa $\mathrm{z}$ obowiązku przestrzegania fundamentalnych zasad MPH, tj. ochrony ludności cywilnej i obiektów cywilnych zgodnie z zasadą rozróżniania

9 Report of the Special Rapporteur on the promotion and protection of human rights and fundamental freedoms while countering terrorism, Ben Emmerson, 18.9.2013 r. A/68/389, [dalej Emmerson Report], pkt 24.

10 Por. Ł. KuŁaga, Używanie Dronów w celu zwalczania terroryzmu świetle ius ad bellum, "Zeszyty Prawnicze«16.2/2016, s. 141 i n.

11 Draft articles on Responsibility of States for Internationally Wrongful Acts, with commentaries 2001, »Yearbook of the International Law Commission« 2-2/2001, s. 73. 
oraz zakazem powodowania nadmiernego cierpienia kombatantów ${ }^{12}$ oraz MPPC.

\section{ISTNIENIE KONFLIKTU ZBROJNEGO. UŻYCIE DRONÓW} A KWALIFIKACJA KONFLIKTU ZBROJNEGO

Ocena zastosowania dronów w celu zwalczania terroryzmu międzynarodowego jest uzależniona w pierwszej kolejności od tego, czy są one używane $\mathrm{w}$ ramach konfliktu zbrojnego. $\mathrm{Z}$ międzynarodowym konfliktem zbrojnym mamy do czynienia w sytuacji konfliktu dwóch lub więcej państw oraz do stanu okupacji, bez względu na to czy stan wojny został ogłoszony ${ }^{13}$. W komentarzu MKCK do art. 2 konwencji genewskich wskazuje się, że konfliktem zbrojnym jest „każdy spór międzypaństwowy prowadzący do interwencji sił zbrojnych"14.

Podstawowa regulacja dotycząca niemiędzynarodowych konfliktów zbrojnych znajduje się w artykule 3 wspólnym dla czterech konwencji genewskich z 1949 r. Przepis ten nie definiuje jednakże tych konfliktów, wskazując jedynie, że jest to konflikt zbrojny na terytorium jednej stron

12 MTS określa te zasady jako kardynalne oraz nienaruszalne zasady międzynarodowego prawa humanitarnego, por. Opinia doradcza MTS w sprawie legalności groźby lub użycia broni jądrowej, ICJ. Rep. 1996, \$ 78-79; nt. autonomii ius in bello względem ius ad bellum por. E. Mikos-SkuzA, Autonomia 'iuris in bello' względem 'ius ad bellum' - współczesne wyzwania, [w:] 'Fides et bellum' - Księga poświęcona Pamięci Księdza Biskupa, Profesora, Generała, śp. Tadeusza Płoskiego, red. B. SiteK, T. Jasudowicz, M. Seroka, Olsztyn 2012, I, s. 395-405.

13 Por. artykuł 2 wspólny dla czterech konwencji genewskich z 1949 r. Ponadto art. 1 ust 4 Protokół dodatkowy do konwencji genewskich z 1949 r. dotyczący ochrony ofiar międzynarodowych konfliktów zbrojnych z 1977 r. (Dz.U. z 1992 r. Nr 41, poz. 175, załącznik) określa, że międzynarodowy konflikt zbrojny obejmuje również „konflikty zbrojne, w których ludy walczą przeciw panowaniu kolonialnemu i obcej okupacji oraz przeciw reżimom rasistowskim, wykonując swe prawo do samostanowienia zawarte w Karcie Narodów Zjednoczonych oraz w Deklaracji w sprawie zasad prawa międzynarodowego dotyczących przyjaznych stosunków i współpracy między państwami, zgodnie z Kartą Narodów Zjednoczonych”.

14 Por. wersja komentarza z 1952 r. https://www.icrc.org/applic/ihl/ihl.nsf/ INTRO/365?OpenDocument, dostęp 29 listopada 2016 r. 
konwencji nieposiadający charakteru międzynarodowego. Konwencje genewskie nie zawierają przy tym żadnego postanowienia dotyczącego wymogu intensywności konfliktu czy też progu skali działań, od którego można stwierdzić jego istnienie. Odmiennie art. 1 ust. 1 II Protokołu dodatkowego z 1977 r. określa, że „niemiędzynarodowy konflikt zbrojny oznacza konflikt między siłami zbrojnymi jednego państwa, a rozłamowymi siłami zbrojnymi lub innymi zorganizowanymi uzbrojonymi grupami, pozostającymi pod odpowiedzialnym dowództwem i sprawującymi taką kontrolę nad częścią jej terytorium, że mogą przeprowadzać ciągłe i spójne operacje wojskowe” ${ }^{\prime 1}$. Zgodnie z artykułem 1 ust. 2 II Protokołu dodatkowego niemiędzynarodowego konfliktu zbrojnego nie stanowią ,wewnętrzne napięcia i niepokoje, jak rozruchy, odosobnione i sporadyczne akty przemocy oraz inne działania podobnego rodzaju"16. Dla istnienia niemiędzynarodowego konfliktu zbrojnego powinien istnieć zatem minimalny poziom intensywności i trwania. W tym kontekście wskazuje się na istnienie dwóch reżimów prawnych dotyczących niemiędzynarodowych konfliktów zbrojnych - konwencyjnego oraz tego wynikającego z protokołu dodatkowego ${ }^{17}$. Współcześnie istotnym punktem odniesienia dla oceny istnienia niemiędzynarodowego konfliktu zbrojnego jest również definicja sformułowana przez

\footnotetext{
15 Dz.U. z 1992 r. Nr 41, poz. 175, załącznik.

16 Komentując ten przepis, międzyamerykańska komisja ds. praw człowieka w sprawie Juan Carlos Abella zauważyła, że „linia oddzielająca szczególnie pełne przemocy sytuacje zamieszek wewnętrznych od najniższego poziomu [...] konfliktu zbrojnego może czasami być niewyraźna i nie łatwa do oceny. Będąc postawionym przed koniecznością przeprowadzenia takiej oceny, konieczna dla ostatecznej analizy jest dobra wiara oraz obiektywna ocena faktów w każdej konkretnej sprawie”, Juan Carlos Abella przeciwko Argentynie, Report No 55/97, Annual Report 1997, § 153.

17 ILA Final Report 2010, s. 13; Znaczenie tego rozróżnienia wydaje się o tyle niewielkie, że II Protokół spotkał się z niezwykle szerokim poparciem, a jego stronami jest obecnie 168 państw, por. https://www.icrc.org/applic/ihl/ihl.nsf/States.xsp?xp_ viewStates=XPages_NORMStatesParties\&xp_treatySelected $=475$. Niemniej stronami tego Protokołu nie są m.in. Irak, Iran, Izrael oraz Stany Zjednoczone. Dla porównania, stronami Konwencji genewskich jest 196 państw, por. https://www.icrc.org/applic/ihl/ ihl.nsf/States.xsp?xp_viewStates=XPages_NORMStatesParties\&xp_treatySelected=375; por. również R. BIERZANeK, Wojna a prawo międzynarodowe, Warszawa 1982, s. 13-18.
} 
Międzynarodowy Trybunał ds. Zbrodni w Byłej Jugosławii (MTKJ) w sprawie Tadica: „konflikt zbrojny istnieje zawsze wtedy, gdy następuje [...] przedłużająca się przemoc zbrojna pomiędzy władzami rządowymi a zorganizowanymi grupami zbrojnymi lub pomiędzy takimi grupami wewnątrz państwa ${ }^{18 ”}$.

Co znaczące, ujęcie to zostało wprowadzone do Statutu Międzynarodowego Trybunału Karnego ${ }^{19}$. Podobną definicję zaproponowało Stowarzyszenie Prawa Międzynarodowego wskazując, że dwa minimalne kryteria dla zaistnienia konfliktu zbrojnego to istnienie zorganizowanych grup zbrojnych oraz ich zaangażowanie w walkę o pewnym stopniu intensywności ${ }^{20}$.

W świetle II Protokołu dodatkowego niepaństwowy podmiot - strona konfliktu zbrojnego - powinien pozostawać pod odpowiedzialnym dowództwem oraz sprawować kontrolę nad częścią terytorium umożliwiającą przeprowadzanie ciągłych i spójnych operacji wojskowych. Współcześnie znaczenie i zastosowanie tych kryteriów podważa praktyka międzynarodowych sądów karnych, które sformułowały nieco odmienne rozwiązanie w tym zakresie. W sprawie Milosevic dotyczącej konfliktu w Kosowie MTKJ stwierdził, że kontrola nad terytorium przez powstańców nie jest wymogiem dla zaistnienia niemiędzynarodowego konfliktu zbrojnego. Trybunał wziął natomiast pod uwagę skalę działań serbskich, w szczególności ilość sił wojskowych oraz rodzaj użytej broni,

18 Prokurator przeciwko Dusko Tadic, wyrok z 2.10.1995 r., IT-94-1-T, §70; Wymóg „przedłużającej się przemocy zbrojnej był przy tym interpretowany jako odnoszący się bardziej do intensywności przemocy zbrojnej, aniżeli do jej trwania”, Prokurator przeciwko Ramush Haradinaj, Idriz Balaj, Lahi Brahimaj, wyrok izby procesowej z 3.4.2008 r., IT-04-84-T, $\$ 49$.

19 Art. 8 ust.2 lit f Statutu MTK stanowi, że „ustęp 2(e) ma zastosowanie do konfliktów zbrojnych, które nie mają charakteru międzynarodowego; nie ma więc zastosowania do wewnętrznych zamieszek i napięć, takich jak bunty oraz odizolowane i sporadyczne akty przemocy lub inne działania o podobnym charakterze; ma natomiast zastosowanie do konfliktów zbrojnych, mających miejsce na terytorium państwa, gdzie toczy się przedłużający się konflikt zbrojny między władzami państwowymi a zorganizowanymi, zbrojnymi ugrupowaniami lub pomiędzy takimi ugrupowaniami”.

20 International Law Association, Final Report on the Meaning of Armed Conflict in International Law, The Hague Conference (2010), s. 32-33 
jak również zasięg konfliktu² ${ }^{21}$ W sprawie Limaj MTKJ uznał, że wystarczający jest jedynie „pewien stopień organizacji” podmiotu niepaństwowego, niekonieczne jest przy tym udowodnienie, że podmiot ten musi być zdolny implementować międzynarodowe prawo humanitarne ${ }^{22}$.

MTK w sprawie Lubangi Dyilo stwierdził, że istnieje różnica w pojmowaniu niemiędzynarodowego konfliktu zbrojnego między Statutem MTK a prawem humanitarnym polegająca na tym, że Statut nie zawiera wymogu, aby zorganizowane grupy zbrojne sprawowały taką kontrolę nad częścią terytorium, która pozwoli im na wykonywanie trwałych i uzgodnionych działań wojennych ${ }^{23}$.

W świetle tych czynników ocena, czy poza terytorium Afganistanu i Pakistanu można stwierdzić istnienie generalnego niemiędzynarodowego konfliktu zbrojnego pomiędzy Stanami Zjednoczonymi a Al-Kaidą i jej sprzymierzonymi siłami, wydaje się problematyczna ${ }^{24}$. Podstawowe trudności w tym zakresie odnoszą się zarówno do kwestii wykazania odpowiedniego stopnia organizacji Al-Kaidy i jej sił stowarzyszonych ${ }^{25}$, jak również uznania istnienia odpowiedniego stopnia intensywności walk. Można wysunąć również wątpliwości, czy sporadyczne używanie bezzałogowych samolotów przeciwko Al.-Kaidzie spełnia wymóg poziomu intensywności.

${ }^{21}$ Prokurator przeciwko Slobodan Milosevic, Decyzja dotycząca wniosku o uniewinnienie z 16.6. 2004, \$ 19 i n..; W tym kontekście trafnie wskazuje się, że „wymóg terytorialnej kontroli przez rebeliantów nie jest oparty na wielkości terytorium lub czasie trwania i stopniu kontroli. Odnosi się on raczej do jakości kontroli, która umożliwia powstańcom wykonywanie władzy i przeprowadzanie operacji wojskowych. W obliczu wojny partyzanckiej i współcześnie wysoce mobilnych działań zbrojnych kontrola terytorialna może się stale zmieniać", R. Oтто, Targeted Killings and International Law - with Special Regards to Human Rights and International Humanitarian Law, Heidelberg 2012, s. 237.

22 Prokurator przeciwko Limaj, wyrok z 30.11.2005 r., IT-03-66-T, § 88-89.

23 Wyrok Izby z 14 marca 2012 r. ICC-01/04-01/06, \$ 536.

24 W 2010 r. Departament Stanu Stanów Zjednoczonych w raporcie przedłożonym Wysokiemu Komisarzowi Praw Człowieka w związku powszechnym przeglądem okresowym wskazał, że Stany Zjednoczone znajdują się w niemiędzynarodowym konflikcie zbrojnym z Al. Kaidą, por. www.state.gov/documents/organization/146379. pdf., $\$ 84$, dostęp 29 listopada 2016 r.

25 Heyns Report, $\$ 65$. 
Kwestią kontrowersyjną jest, na ile do niemiędzynarodowych konfliktów zbrojnych może być stosowana koncepcja kobeligerenta znana międzynarodowym konfliktom zbrojnym ${ }^{26}$. Zakłada ona, że państwo może stać się stroną konfliktu zbrojnego w sytuacji zapewniania pomocy innemu państwu będącemu już stroną konfliktu. Przyjęcie tej teorii w niemiędzynarodowych konfliktach zbrojnych pozwala na znaczne rozszerzenie podmiotów, które mogą być przedmiotem ataku w świetle międzynarodowego prawa humanitarnego ${ }^{27}$. Warto w tym kontekście przywołać trafne stanowisko byłego doradcy prawnego Stanów Zjednoczonych H. Kocha: „jeżeli poniesiemy porażkę w zakresie ustalania, kogo uważamy za część sił powiązanych z Al-Kaidą, wtedy zawsze będziemy mieć nowych wrogów i wieczna wojna będzie trwała wiecznie"28.

\subsection{Legitymizowane cele zbrojnych}

bezzałogowych statków powietrznych

W międzynarodowych konfliktach zbrojnych kombatanci mogą być przedmiotem ataku na warunkach określonych przez międzynarodowe prawo humanitarne. Artykuł 43 ust. 2 I Protokołu dodatkowego do Konwencji genewskich określa, że „Członkowie sił zbrojnych strony konfliktu (inni niż personel medyczny i duchowny objęty artykułem 33 Trzeciej Konwencji) są kombatantami, to jest mają prawo bezpośredniego uczestniczenia w działaniach zbrojnych”. Ponadto zgodnie $\mathrm{z}$ art. 52 ust. 2 tego protokołu „Ataki powinny być ściśle ograniczone do celów wojskowych. Co się tyczy dóbr, celami wojskowymi są tylko takie, które

26 G.S. Conn, D. Brenner, The War on Terror and the Laws of War: A Military Perspective, Oxford 2015, s. XXII.

27 Por. w tym kontekście wystąpienia Prezydenta Stanów Zjednoczonych „pojawiły się różne oddziały Al. Kaidy oraz grupy ekstremistyczne od Półwyspu Arabskiego po Afrykę. Zagrożenie, jakie te grupy stwarzają, ewoluuje. [...] kiedy to konieczne, poprzez różnego rodzaju zdolności będziemy kontynuowali podejmowanie bezpośrednich działań przeciwko tym terrorystom, którzy stwarzają najpoważniejsze zagrożenie względem Amerykanów", por. https://www.whitehouse.gov/the-press-office/2013/02/12/ remarks-president-state-union-address, dostęp 29 listopada 2016 r.

28 H.H. КoH, How to End the Forever War?, Oxford 7.5.2013 r., por. https://www. justsecurity.org/wp-content/uploads/2013/10/Koh-Oxford-How-to-End-the-Forever-War.pdf, s. 4, dostęp 29 listopada 2016 r. 
z powodu swej natury, swego rozmieszczenia, swego przeznaczenia lub wykorzystania wnoszą istotny wkład do działalności wojskowej i których całkowite lub częściowe zniszczenie, zajęcie lub zneutralizowanie daje określoną korzyść w danej sytuacji”29.

Mając zatem na względzie fakt, że kombatanci mogą być przedmiotem ataku w ramach międzynarodowych konfliktów zbrojnych ${ }^{30}$, kwestia stosowania ZBSP do ich zabicia prima facie nie wydaje się być przedmiotem kontrowersji, aczkolwiek można spotkać poglądy, że używanie dronów naruszałoby zasadę humanitaryzmu, ponieważ uniemożliwia kombatantowi poddanie się ${ }^{31}$. W tym kontekście trafnie wskazują Marco Sassoli oraz Laura Olson, że „na polu bitwy aresztowanie przeciwnika jest zazwyczaj niemożliwe bez wystawienia sił rządowych na nieproporcjonalne niebezpieczeństwo"32. Poza kombatantami legalnym celem ataku w międzynarodowym konflikcie zbrojnym mogą być również osoby cywilne uczestniczące bezpośrednio w działaniach zbrojnych zgodnie

29 Przepis ten może być jednak różnie interpretowany: „Możemy interpretować artykuł 52 ust. 2 jako pozwalający atakowanie tylko tych obiektów, które przyczyniają się do wysiłku wojskowego mając na myśli kinetyczne zaatakowanie sił wroga. Alternatywnie za wystarczający może być uznane jedynie bardziej szerokie powiązanie $\mathrm{z}$ wysiłkiem wojennym. Ta ostatnia interpretacja pozostawia znaczenie większą przestrzeń na niszczenie obiektów strony przeciwnej”, J. DiLL, The 21st-Century Belligerent's Trilemma, «EJIL» 26.1/2015, s. 85.

30 “Zasada 1. Strony konfliktu powinny zawsze rozróżniać osoby cywilne i kombatantów. Ataki mogą być kierowane jedynie przeciwko kombatantom. Ataków nie wolno kierować przeciwko osobom cywilnym", J.-M. HenckAerTs, Study on customary international law: A contribution to the understanding and respect for the rule of law in armed conflict, "International Review of the Red Cross» 87.857/2005, s. 198.

31 Pogląd taki referuje Agnieszka Szpak, aczkolwiek trudno stwierdzić, czy autorka go podziela, por. A. SzPAK, Selektywna eliminacja w międzynarodowym prawie humanitarnym, Międzynarodowe Prawo Humanitarne - Selektywna eliminacja i rozkaz wojskowy, IV, Gdynia 2013 s. 36-37; Autorka wyraźnie prezentuje natomiast taki pogląd w innej publikacji, A. SzPak, Dopuszczalność pozbawienia życia kombatanta wświetle międzynarodowego prawa humanitarnego, «Polski Rocznik Praw Człowieka i Prawa Humanitarnego» 6/2015, s. 207-227.

32 M. Sassoli, L. M. Olson, The Relationship Between International Humanitarian Law and Human Rights Law Where it Matters: Admissible Killing and Internment of Fighters in Non-International Armed Conflicts, «International Review of the Red Cross» $90.871 / 2008$, s. 613 . 
z art. 51 ust. 3 I Protokołu dodatkowego. Należy równocześnie pamiętać, że przeprowadzania ataków w każdym konflikcie zbrojnym powinno być zgodne z zasadami proporcjonalności ${ }^{33}$ oraz ostrożności ${ }^{34}$ obowiązującymi zarówno na gruncie traktatów, jak i prawa zwyczajowego.

W niemiędzynarodowych konfliktach zbrojnych kluczowe pojęcia to „członek zorganizowanej grupy zbrojnej” ${ }^{35}$ oraz „osoba biorąca bezpośredni udział w działaniach zbrojnych" ${ }^{36}$. W tym zakresie MKCK przyjął w 2009 r. Wytyczne interpretacyjne ${ }^{37}$. W rekomendacji V Wytycznych dotyczącej elementów konstytutywnych „bezpośredniego udziału w działaniach zbrojnych” stwierdza się: „W celu uznania za

33 „Zasada 14. Zakazane jest wszczynanie ataku, co do którego można przypuszczać, że wywoła również straty w życiu ludzkim wśród ludności cywilnej, ranienia osób cywilnych, szkody w dobrach o charakterze cywilnym lub połączenie tych strat i szkód, jeśli byłyby one nadmierne w porównaniu z oczekiwaną konkretną i bezpośrednią korzyścią wojskową", J.-M. HenckaerTs, op. cit., s. 199; Art. 51 ust. 5 pkt (b) I Protokołu dodatkowego.

34 „Zasada 15. W trakcie prowadzenia operacji wojskowych należy stale troszczyć się o oszczędzanie ludności cywilnej, osób cywilnych oraz dóbr o charakterze cywilnym. Należy przedsięwziąć wszystkie praktycznie możliwe środki ostrożności w celu uniknięcia, a przynajmniej sprowadzenia do minimum, nie-zamierzonych strat w życiu ludzkim wśród ludności cywilnej, ranienia osób cywilnych i szkód w dobrach o charakterze cywilnym.”, Ibidem; Art. 57 i 58 I Protokołu dodatkowego.

35 Chodziłoby tu w szczególności o tzw. „rozłamowe siły zbrojne lub zorganizowane uzbrojone grupy", o których wspomina art. 1 ust. 1 II Protokołu dodatkowego.

36 Art. 4 ust. 1 II Protokołu dodatkowego stanowi, że: „1. Wszystkie osoby, które nie biorą bezpośredniego udziału w działaniach zbrojnych lub które zaniechały takiego udziału, mają prawo - niezależnie od tego, czy ich wolność została ograniczona, czy nie - do poszanowania ich osoby, godności, przekonań i praktyk religijnych. We wszystkich wypadkach należy je traktować w sposób humanitarny, bez czynienia jakichkolwiek różnic na niekorzyść. Zabronione jest wydawanie rozkazu, by nikogo nie zostawiać przy życiu”.

37 Wytyczne formalnie nie stanowią wiążącego prawa międzynarodowego, niemniej wzrasta praktyka państw opierająca na nich swoje postępowanie, por. Heyns Report, $\$ 70 ; n t$. kontrowersji dotyczących niektórych elementów Wytycznych por. D. AKAndE, Clearing the Fog of War? The ICRC'S Interpretive Guidance on Direct Participation In Hostilities, «International and Comparative Law Quarterly» 59/2010, s. 180-192 oraz P. Grzeby к, Pojęcia „osoba cywilna” oraz „bezpośredni udział w działaniach zbrojnych” (wytyczne Międzynarodowego Komitetu Czerwonego Krzyża), «PiP»67.2/2012, s. 60-72. 
bezpośredni udział w działaniach zbrojnych, konkretny akt powinien spełniać kumulatywnie następujące kryteria:

1. Akt powinien prawdopodobnie negatywnie oddziaływać na działania wojskowe lub zdolność wojskową strony konfliktu zbrojnego lub alternatywnie powodować śmierć, rany, lub szkody osobom lub obiektom chronionym przed bezpośrednim atakiem (wymóg szkody), i

2. Musi istnieć bezpośredni związek przyczynowy pomiędzy aktem i szkodą prawdopodobnie wynikającą albo z tego aktu, albo ze skoordynowanych operacji wojskowych, w ramach których ten akt stanowi ich integralną część (bezpośredni związek przyczynowy), i

3. Akt powinien być specjalnie zaplanowany, aby bezpośrednio spowodować wymagany próg szkody w ramach wsparcia dla jednej ze stron konfliktu oraz ze szkodą dla drugiej (związek ze stroną wojującą)”38.

Wytyczne określają również, że „ludność cywilna traci ochronę przed bezpośrednimi atakami w czasie trwania każdego konkretnego aktu, który jest równoważny $\mathrm{z}$ bezpośrednim udziałem $\mathrm{w}$ działaniach zbrojnych, natomiast członkowie zorganizowanych grup zbrojnych należących do strony niepaństwowej konfliktu zbrojnego przestają być ludnością cywilną i tracą ochronę przed bezpośrednimi atakami tak długo, jak przyjmują trwającą funkcję bojową" (ang. continuous combat function $)^{39}$. Trwająca funkcja bojowa nie oznacza przyznania osobie ją realizującej statusu kombatanta, a raczej pozwala odróżnić członków zorganizowanych grup zbrojnych, którzy podejmują funkcje bojowe w ramach sił niepaństwowej strony konfliktu, od osób cywilnych, które biorą bezpośredni udział w działaniach zbrojnych, lecz jedynie sporadycznie, spontanicznie i w sposób niezorganizowany ${ }^{40}$. W tym kontekście w komentarzu do Wytycznych podkreśla się, że kluczową przesłanką ochrony lub jej braku jest kwestia członkostwa danej osoby w zorganizowanej grupie zbrojnej ${ }^{41}$.

38 Interpretive guidance on the notion of Direct participation in hostilities under international humanitarian law, por. https://www.icrc.org/eng/assets/files/other/icrc002-0990.pdf, dostęp 29 listopada 2016 r.

39 Ibidem, s. 70 oraz s. 72.

40 Ibidem, s. 33-34.

41 Ibidem, s. 72. 
Kontrowersyjnym elementem Wytycznych jest stwierdzenie, że względem osób biorących bezpośredni udział w działaniach zbrojnych państwo-strona konfliktu zbrojnego powinna najpierw poszukiwać mniej śmiercionośnych metod ${ }^{42}$. W rezultacie nawet uznanie osoby za mieszczącą się w zakresie możliwych celów ataków nie oznacza, że atak taki może być przeprowadzony. Konieczna jest ewaluacja, czy jest to rzeczywiście konieczne. W tym kontekście zasada konieczności wojskowej odgrywa restrykcyjną, a nie permisywna rolę ${ }^{43}$. Wcześniej podobne stanowisko przedstawił w orzeczeniu w sprawie ukierunkowanych zabójstw z 2006 r. Sąd Najwyższy Izraela, który uznał, że: „ludność cywilna, która bierze bezpośredni udział w działaniach zbrojnych, może być celem legalnych ataków, tylko jeżeli są spełnione cztery przesłanki: 1. Państwo posiada dobrze ugruntowaną, rzetelnie zweryfikowaną informację dotyczącą tożsamości i aktywności cywila, któremu zarzuca się branie udziału w działaniach zbrojnych. Ciężar dowodu spoczywający na państwie jest wysoki; 2. Osoba cywilna biorąca bezpośredni udział w działaniach zbrojnych nie może być zaatakowana w momencie uczestnictwa, jeżeli możliwe jest zastosowanie mniej szkodliwych środków. Zatem, jeżeli terrorysta biorący bezpośredni udział w działaniach zbrojnych może zostać zaaresztowany, przesłuchany i osądzony, to są środki, które powinny być zastosowane [...] 3. Jeżeli osoba cywilna została rzeczywiście zaatakowana, powinno być przeprowadzone rzetelne i niezależne śledztwo dotyczące precyzji w zakresie identyfikacji celu oraz okoliczności ataku [...] 4. Wreszcie, kombatanci i terroryści nie powinni być przedmiotem ataku, jeżeli spodziewana szkoda, która może być wyrządzona pobliskiej ludności cywilnej, jest nieproporcjonalna

42 Podobnie R. Goodman, The Power to Kill or Capture Enemy Combatants, «EJIL» 24.3/2013, s. 819-820.

43 N. Melzer, Targeted Killing in International Law, Oxford, 2008, s. 278; Krytycznie w tym zakresie W. H. PArks, Part IX of the ICRC "Direct Participation in Hostilities" Study: No Mandate, No Expertise, and Legally Incorrect, "Journal International Law and Politics» 42/2010, s. 828-830. 
w stosunku do korzyści wojskowej oczekiwanej bezpośrednio $\mathrm{z}$ ataku na kombatanta lub terrorystę"44.

Komentując to rozstrzygnięcie, Marco Milanovic zauważył, że jedynie ostatni z tych wymogów wynika expressis verbis z prawa humanitarnego, a trzy pierwsze z orzecznictwa ETPC. W rezultacie okazuje się, że izraelski Sąd Najwyższy wykorzystał normy z zakresu MPPC do ograniczenia możliwości zastosowania $\mathrm{MPH}^{45}$. To ostatnie wydaje się bowiem być jasne $\mathrm{w}$ zakresie obowiązku poszukiwania mniej śmiercionośnych metod względem osób biorących bezpośredni udział w działaniach zbrojnych: „Żaden traktat nie ustanawia takiej reguły ani nie zaistniała wystarczająca praktyka państw połączona z opinio iuris, aby stworzyły zwyczaj międzynarodowy"46. Warto zatem odnieść się do możliwości zastosowania MPPC w trakcie konfliktu zbrojnego.

2.2 Międzynarodowe prawo humanitarne a międzynarodowe prawo praw człowieka

Reżim MPPC nie przestaje obowiązywać w trakcie konfliktu zbrojnego ${ }^{47}$. Międzynarodowy Trybunał Sprawiedliwości w opinii doradczej w sprawie legalności użycia lub groźby użycia broni jądrowej stwierdził: „Trybunał uważa, że ochrona wynikająca z Międzynarodowego paktu praw obywatelskich i politycznych nie wygasa w trakcie wojny,

44 Israel High Court of Justice, The Public Committee Against Torture et al. v. The Government of Israel et al., HCJ 769/02, wyrok z 14 lutego 2006 r., $\$ 40$; por. w tym kontekście stanowisko: „Stany Zjednoczone nie inicjują ataków, jeżeli posiadają zdolności do schwytania indywidualnego terrorysty; naszą preferencją jest zawsze, aby zatrzymać, przesłuchać i wszcząć postępowanie karne”, President Obama’s counterterrorism policy speech, National Defense University - Fort McNair, Washington, D.C., 23.5.2013 r.

45 M. Milanovic, Lessons for human rights and humanitarian law in the war on terror: comparing Hamdan and the Israeli Targeted Killings case, «International Review of the Red Cross» 89.866/2007, s. 389-391.

46 M. N. Schmitт, Wound, Capture, or Kill: A Reply to Ryan Goodman's 'The Power to Kill or Capture Enemy Combatants', «EJIL» 24.3/2013, s. 861.

47 Por. aneks do Artykułów Komisji Prawa Międzynarodowego w zakresie wpływu konfliktów zbrojnych na traktaty, «Yearbook of the International Law Commission» $2.2 / 2011$. 
poza sytuacją działania artykułu 4 Paktu, na podstawie którego niektóre postanowienia mogą być uchylone w sytuacji stanu wyjątkowego. Ochrona prawa do życia nie jest jednakże tego rodzaju postanowieniem. Zasadniczo, prawo do bycia niepozbawionym arbitralnie życia znajduje zastosowanie również w czasie działań wojennych. Niemniej, opinia, co stanowi arbitralne pozbawienie życia, powinna być ustalona na podstawie mającego zastosowanie lex specialis, tj. przez prawo mające zastosowanie w konfliktach zbrojnych, które jest ustanowione, aby regulować sposób prowadzenia działań wojennych" ${ }^{\prime 4}$.

Trybunał rozwinął przedmiotową tezę w opinii doradczej w sprawie prawnych konsekwencji budowy muru na palestyńskich terytoriach okupowanych, gdzie wskazał: „Jeśli chodzi o relację pomiędzy MPH a MPPC istnieją zatem trzy możliwe sytuacje: niektóre prawa mogą być wyłącznie przedmiotem MPH; inne mogą być wyłącznie przedmiotem MPPC; wreszcie inne mogą być przedmiotem obu tych gałęzi prawa międzynarodowego. [...] Trybunał będzie musiał wziąć pod uwagę obie gałęzie prawa międzynarodowego, w szczególności MPPC, oraz jako lex specialis $\mathrm{MPH}^{\prime 49}$.

Wzrost znaczenie MPPC w kontekście konfliktów zbrojnych wiąże się z faktem stosowania tego działu prawa przez organy ochrony praw człowieka do sytuacji, które stanowią konflikt zbrojny ${ }^{50}$. W sprawie Hasan przeciwko Zjednoczonemu Królestwu ETPC zauważył: „nawet w trakcie międzynarodowego konfliktu zbrojnego, ochrona wynikająca z Konwencji nadal obowiązuje, niemniej jest interpretowana w kontekście postanowień MPH. Przez fakt koegzystencji ochrony gwarantowanej przez MPH oraz przez Konwencję w czasie konfliktu zbrojnego, podstawy dla legalnego pozbawienia wolności [...] powinny być dostosowane, $\mathrm{w}$ jak największym stopniu, w jakim to możliwe, do brania jeńców wojennych

48 ICJ Rep. 1996, 226, \$ 25; Podobnie Komitet Praw Człowieka w Komentarzu ogólnym nr 29 z 24.7.2001 r., A/56/40, pkt 3.

49 ICJ. Rep. 2004, \$106; podobnie MTS w sprawie zbrojnych działań na terytorium Konga (Demokratyczna Republika Kongo przeciwko Ugandzie), ICJ Rep. 2005, § 216.

50 Isayeva, Yusupova and Bazayeva przeciwko Rosji, nr skargi 57947/00, 57948/00 and 57949/00, wyrok z 24 lutego 2005 r.; Isayeva przeciwko Rosji, nr skargi 57950/00, wyrok z 24 lutego 2005 r. 
oraz przetrzymywania cywilów, którzy stanowią zagrożenie dla bezpieczeństwa na podstawie Trzeciej i Czwartek Konwencji Genewskiej"51. Podobnie Komitet Praw Człowieka stoi na stanowisku, że „obie przestrzenie prawa są komplementarne, a nie wzajemnie wyłączające" ${ }^{2}$, a Międzyamerykańska Komisja ds. Praw Człowieka zauważyła istnienie „wspólnego rdzenia praw niederogowalnych oraz wspólnego celu ochrony ludzkiego życia i godności” w obu dziedzinach prawa ${ }^{53}$.

Cezary Mik zauważa, że w odniesieniu do MPH międzynarodowe prawo praw człowieka odgrywa rolę uzupełniającą oraz wspierającą. Ich relacja wzajemna „nie powinna być postrzegana jako relacja dziedzin czy reżimów prawnych, ale dużo bardziej konkretnie, co najmniej na poziomie stosunku konkretnych norm, a nawet na jeszcze [niższym - przyp. ŁK] poziomie, tj. jako relacja zobowiązań (w szczególności samych obowiązków)" ${ }^{34}$. Stwierdza równocześnie różnice pomiędzy tymi dziedzinami prawa, zauważając, że możliwość odwołania się do reguły lex specialis jest ograniczona i nie może być ona stosowana mechanicznie. „Odwołanie się do niej należy poprzedzić dążeniem do harmonijnej wykładni lub łącznego stosowania norm obu dziedzin”55.

51 Pkt 104. Ponadto Trybunał zauważył, że „pozbawienie wolności zgodnie z uprawnieniami na podstawie międzynarodowego prawa humanitarnego musi być legalne, aby wyłączyć naruszenie art. 5 ust 1. Oznacza to, że zatrzymanie musi być zgodne $z$ regułami międzynarodowego prawa humanitarnego i co ważne, powinno być zgodne z fundamentalnymi celami Artykułu 5 ust. 1, tj. ochroną jednostki przed arbitralnością", Hassan przeciwko Zjednoczonemu Królestwu, nr skargi 29750/09, wyrok Wielkiej Izby z 16 września 2014 r., pkt 105.

52 Komentarz ogólny nr 29 Komitetu Praw Człowieka w sprawie stanów wyjątkowych z 24.7.2001 r.

53 Juan Carlos Abella (“La Tablada”), Annual Report (1997), § 158.

54 С. Мıк, Obowiązywanie i stosowanie traktatów chroniących prawa człowieka w czasie wojny, [w:] 'Fides et bellum'..., s. 346-347; podobnie M. Milanovic, A Norm Conflict Perspective on the Relationship between International Humanitarian Law and. Human Rights Law, "Journal of Conflict and Security Law»14.3/2009, s. 459 i n.

55 C. Mik, op. cit., s. 347; Odmiennie poglądy prezentuje Jordan Paust, który wskazuje, że „Międzynarodowe prawo człowieka generalnie obowiązuje na polu bitwy i terytoriach okupowanych. Nie istnieje lex specialis prawa wojennego, która odrzucałaby możliwość zastosowania praw człowieka w trakcie wojny", J. J. PAUst, Human rights on the battlefield, «The George Washington International Law Review» 47/2015, 
Podobnie M. Sassoli oraz L. Olson uważają, że „zasada lex specialis nie określa abstrakcyjnie priorytetów pomiędzy dwoma regułami, ale oferuje rozwiązania do konkretnych przypadków, w których współistniejące reguły prowadzą do odmiennych rezultatów" ${ }^{36}$. Autorzy ci proponują równocześnie kryteria, na podstawie których możnaby stwierdzić pierwszeństwo zastosowania MPPC lub MPH. W ich opinii na rzecz zastosowania tego pierwszego przemawia istnienie kontroli rządowej nad terytorium miejsca, gdzie może zostać użyta broń. Równocześnie jednak zastrzegają, że we wszelkich sytuacjach granicznych należy stosować domniemanie na rzecz pierwszeństwa zastosowania $\mathrm{MPH}^{57}$. Philip Alston sugeruje możliwość odwołania się do MPPC w sytuacji, gdy MPH nie reguluje danej sytuacji lub reguluje daną sytuację w sposób niejasny, a zasady MPH nie są wystarczająco pomocne dla potrzeb interpretacji ${ }^{58}$. Warto jednak w tym kontekście pamiętać o kontrowersjach dotyczących możliwości rozciągnięcia zobowiązań wynikających z MPPC na podmioty niepaństwowe.

2.3. Zakres terytorialny konfliktu zbrojnego a użycie dronów

Zakres terytorialny niemiędzynarodowego konfliktu zbrojnego toczone przez Stany Zjednoczone został sprecyzowany w następujący sposób: „Poza obszarem Afganistanu, atakujemy jedynie Al.-Kaidę oraz powiązane z nią siły. I nawet wtedy stosowanie dronów jest znacząco ograniczone. [...] Stany Zjednoczone nie mogą dokonywać ataków

s. 561; Natomiast Philip Alston, Jason Morgan-Foster oraz William Abreschs wskazują, że „MPPC jest stosowane obok MPH w trakcie konfliktu zbrojnego”, P. Alston, J. Morgan-Foster, W. Abresch, The Competence of the UN Human Rights Council and its Special Procedures in relation to Armed Conflicts: Extrajudicial Executions in the „War on Terror", «EJIL» 19.1/2008, 191-197.

56 M. SAssoli, L. M. Olson, op. cit., s. 613, autorzy zwracają również trafną uwagę, że „Ruchoma skala zastosowania odpowiednio MPPC lub MPH do ataku przeciwko bojownikom w niemiędzynarodowych konfliktach zbrojnych prowadzi do znaczącej niepewności w sytuacjach granicznych i ustanawia różne zobowiązania dla strony rządzącej oraz dla rebeliantów", s. 627.

57 Ibidem, s. 614.

58 Alston Report, pkt 29. 
gdziekolwiek wybiorą; nasze działania są ograniczone konsultacjami z naszymi partnerami oraz poszanowaniem dla suwerenności państwa"59.

W tym kontekście warto przypomnieć, że koncepcja niemiędzynarodowego konfliktu zbrojnego nie zakłada, iż musi on obejmować tylko jedno państwo ${ }^{60}$. MTKJ zauważył, że „niekoniecznie musi istnieć korelacja pomiędzy obszarem, na którym ma miejsce rzeczywista walka, a geograficznym zasięgiem praw wojennych. Prawa wojenne mają zastosowanie na całym terytorium wojujących stron lub w przypadku wewnętrznych konfliktów zbrojnych na całym terytorium znajdującym się pod kontrolą strony takiego konfliktu, bez względu na to, czy rzeczywista walka się tam odbywa" ${ }^{61}$. Niemniej jednak cytowane stanowisko amerykańskiej administracji prima facie zdaje się nie korespondować $z$ doktryną prawa międzynarodowego zakładającą, że o istnieniu konfliktu zbrojnego przesądza intensywność działań zbrojnych na danym terenie ${ }^{62}$.

Niekwestionowanym jest, że zastosowanie MPH jest uzależnione od istnienia konfliktu zbrojnego, który wyraża się w istnieniu działań zbrojnych. Ben Emmerson wskazuje, że „konieczne jest określenie geograficzne zasięgu tego konfliktu w celu ustalenia, czy zasady MPH znajdują zastosowanie do konkretnej operacji. Gdyby było inaczej, prawo pozwalałoby na ataki, które skutkują proporcjonalnymi stratami wśród ludności cywilnej w obszarach, które są poza nimi wolne od działań zbrojnych, co mogłoby podkopywać podstawowe założenia oraz cele $\mathrm{MPH}^{\prime \prime 3}$.

59 President Obama's counterterrorism policy speech, National Defense University - Fort McNair, Washington, D.C., 23.5.2013 r.

60 M. SAssoli, Use and Abuse of the Laws of War in the „War on Terrorism”, "Law and Inequality: A Journal of Theory \& Practice» 22/2004, s. 201

${ }_{61}$ Prokurator przeciwko Dragoljub Kunarac, Radomir Kovač oraz Zoran Vuković, IT-96-23 \& IT-96-23/1-A, wyrok z 12 czerwca 2002 r., \$ 57.

${ }^{62}$ Zastrzec należy jednakże, że lakoniczność amerykańskiego stanowiska uniemożliwia sformułowanie jednoznacznej generalnej oceny.

${ }^{63}$ Emmerson Report, pkt 63; podobny pogląd przedstawił holenderski Komitet doradczy ds. zagadnień międzynarodowego prawa publicznego (Advisory Committee on Issues of Public International Law): „MPH nie ma zastosowania na terytorium państwa trzeciego tylko z tego powodu, że jeden lub więcej członków sił zbrojnych 
Problem ten dobrze odzwierciedlają kontrowersje dotyczące stanowiska amerykańskiego Departamentu Sprawiedliwości z 2011r. w sprawie możliwości użycia siły poza obszarem działań zbrojnych ${ }^{64}$. Kluczowe w tym zakresie jest ustalenie, czy MPH w kontekście niemiędzynarodowego konfliktu zbrojnego może mieć zastosowanie poza „obszarem czynnych działań zbrojnych"65. Podstawy dla twierdzenia, że może mieć

strony prowadzącej wojnę są fizycznie obecni na terytorium tego państwa trzeciego. MPH dopiero zaczyna mieć zastosowanie, jeżeli działania zbrojne są kontynuowane z terytorium państwa trzeciego, a władze tego państwa nie mogą podjąć środków odwetorych lub to zaniedbują", por. Main Conclusions of Advice on Armed Drones, July 2013, s. 2-3.

64 "This white paper sets forth a legal framework for considering the circumstances in which the U.S. government could use lethal force in a foreign country outside the area of active hostilities against a U.S. citizen who is a senior operational leader of alQa'ida or an associated force of al-Qa'ida - that is, an al-Qa' ida leader actively engaged in planning operations to kill Americans. [...] where the following three conditions are met, a U.S. operation [...] would be lawful: (1) an informed; high-level official of the U.S. government has determined that the targeted individual poses an imminent threat of violent attack against the United States; (2) capture is infeasible, and the United States continues to monitor whether capture becomes feasible; and (3) the operation would be conducted in a manner consistent with applicable law of war principles", https://en.wikipedia.org/wiki/020413_DOJ_White_Paper, dostęp 29 listopada 2016 r.; por. również "U.S. Policy Standards and Procedures for the Use of Force in Counter-Terrorism Operations Outside the United States and Areas of Active Hostilities" z 23.5.2013 r. - w dokumencie stwierdzono m.in.: „the following criteria must be met before lethal action may be taken: 1 . Near certainty that the terrorist target is present; 2 . Near certainty that non-combatants will not be injured or killed; 3. An assessment that capture is not feasible at the time of the operation; 4 . An assessment that the relevant governmental authorities in the country where action is contemplated cannot or will not effectively address the threat to U.S. persons; and 5. An assessment that no other reasonable alternatives exist to effectively address the threat to U.S. persons"; https://www. whitehouse.gov/the-press-office/2013/05/23/fact-sheet-us-policy-standards-and-procedures-use-force-counterterrorism, dostęp 29 listopada 2016 r.

${ }^{65}$ W tym zakresie Departament Sprawiedliwości przyjął następujący pogląd: "Particularly in a non-international armed conflict, where terrorist organizations may move their base of operations from one country to another, the determination of whether a particular operation would be part of an ongoing armed conflict would require consideration of the particular facts and circumstances in each case, including the fact that transnational non-state organizations such as al-Qa'ida may have no single 
ono zastosowanie na każdym terytorium, gdzie znajduje się członek zorganizowanej grupy zbrojnej, nawet jeżeli nie występują tam czynne działania zbrojne, są niejasne. Taki pogląd byłby również niespójny z dążeniem państw do ograniczenia możliwości stwierdzenia niemiędzynarodowego konfliktu zbrojnego w sytuacji pojedynczych incydentów, odzwierciedlonym w II Protokole dodatkowym. Jak wskazują N. Lubell oraz N. Derejko, „tylko ataki dronów nie są wystarczające dla stwierdzenie istnienia niemiędzynarodowego konfliktu zbrojnego i zapewnienia zastosowania MPH. Grupa zbrojna musi sama być aktywna stroną konfliktu"66.

Równocześnie podnoszony jest pogląd, że przyjęcie wąskiego spojrzenia na zakres geograficznego konfliktu pozwalałoby członkom sił zbrojnych strony niepaństwowej łatwo znajdować azyl na planowanie kolejnych działań zbrojnych ${ }^{67}$. Istotnym wsparciem dla praktyki i doktryny amerykańskiej w tym zakresie może być stanowisko Francji,

site serving as their base of operations. [...] If an operation of the kind discussed in this paper were to occur in a location where al-Qa'ida or an associated force has a significant and organized presence and from which al-Qa'ida or an associated force, including its senior operational leaders, plan attacks against U.S. persons and interests, the operation would be part of the non-international armed conflict between the United States and al-Qa'ida [...]" s. 5; Krytycznie na ten temat A. Szpak, która twierdzi, że użycie siły śmiercionośnej przeciwko amerykańskiemu obywatelowi w okolicznościach wskazanych w White Paper (poza działaniami zbrojnymi, bez słusznego procesu) jest nielegalne, A. SzPaK, Bezpośredni udział $w$ działaniach zbrojnych $w$ świetle miedzynarodowego prawa humanitarnego, Toruń 2013, s. 213.

${ }^{66}$ N. Lubell, N. Derejko, A global battlefield? Drones and the geographical scope of armed conflict, «Journal of International Criminal Justice»11.1/2013, www. papers.ssrn.com, s. 13, dostęp 29 listopada 2016 r.; Podobnie C. Heyns, D. Akande, L. Hill-Cawthorne, T. Chengeta, op. cit., s. 23.

67 „Realia globalizacji, połączone z proliferacją transnarodowego terroryzmu zapewniają beligerentom możliwości skutecznego przeprowadzenia wrogich działań daleko od aktywnego pola bitwy”, S. R. Reeves, Bin Laden and Awlaki: Lawful Targets, «Harvard International Review», 26.10/2011, s. 2; Podobnie „W przypadku bin Ladena było absurdalne uważać, że nie może on być celem, ponieważ znajduje się $160 \mathrm{~km}$ poza Afganistanem”, D.A Wallace, Operation Neptune's Spear: The lawful killing of Osama bin Laden, «Israel Law Review» 45.2/2012, s. 374; „Dystans nie może być podstawowym determinantem dla zastosowania MPH”, N. Lubell, N. Derejko, op. cit., s. 17. 
która po zamachach terrorystycznych w Paryżu z 13.11.2015 r. uznała się za ofiarę napaści zbrojnej w rozumieniu prawa międzynarodowego. De iure zatem Francja uznała równocześnie, że zamachy z 13.11.2015 r. zainicjowały konflikt zbrojny, przy czym francuska praktyka wydaje się wskazywać, że zakres terytorialny tego konfliktu obejmuje Syrię, a nie Francję $e^{68}$.

W sytuacji niemożliwości stwierdzenia konfliktu zbrojnego stosowanie dronów w ramach polityki ukierunkowanych zabójstw może być oceniane na gruncie MPPC ${ }^{69}$. Ewentualna zgoda państwa na takie działanie na jego terytorium może stanowić usprawiedliwienie dla naruszenia jego suwerenności, natomiast państwo nie może zgodzić się na naruszanie norm $\mathrm{z}$ zakresu MPPC na jego terytorium przez inne państwo. Jednym z podstawowych praw człowieka, regulowanym we wszystkich kluczowych traktatach dotyczących ochrony praw człowieka oraz uznawanych za normę prawa zwyczajowego, jest prawo do życia ${ }^{70}$. Co znaczące, zazwyczaj jest ono określane jako prawo niederegowalne, tj. takie, które nie może zostać uchylone nawet w sytuacji zagrożenia

68 „Ponieważ jesteśmy w stanie wojny, podejmiemy nadzwyczajne działania. Uderzymy w naszego wroga i zniszczymy go, nie tylko we Francji i w Europie, ale też w Syrii i w Iraku - premier Francji Manuel Valls”, J. Kapiszewski, B. NiedzińsKi, Wojna światów, «Dziennik Gazeta Prawna» z 16 listopada 2015 r., A2.

69 Przedmiotem artykułu nie jest zasadniczo kwestia ekstraterytorialnego stosowania traktatów z zakresu ochrony praw człowieka, która z uwagi na swoją objętość wymagałaby odrębnego opracowania. Niemniej, w opinii autora pogląd o możliwości ekstraterytorialnego stosowania traktatów z zakresu ochrony praw człowieka, w szczególności Międzynarodowego Paktu Praw Obywatelskich i Politycznych, wydaje się stosunkowo utrwalony w międzynarodowej praktyce; por. np. Komentarz ogólny Komitetu Praw Człowieka Nr 35, pkt 63; Komentarz ogólny Komitetu Praw Człowieka Nr 31, pkt 10; opinia doradczą Międzynarodowego Trybunału Sprawiedliwości w sprawie prawnych konsekwencji budowy muru na palestyńskim terytorium okupowanym, ICJ. Rep. \$ 108-11; por. szerzej J. J. PAUst, op. cit., s. 527-530.

70 Art. 6 Międzynarodowego pakt praw obywatelskich i politycznych z 1966 r.; Art. 2 Konwencji o ochronie praw człowieka i podstawowych wolności z 1950 r.; Art. 4 Amerykańskiej konwencji praw człowieka z 1969 r.; Art. 4 Afrykańskiej karty praw człowieka i ludów z 1981 r.; por. również Komentarz ogólny Komitetu Praw Człowieka Nr 24, pkt 10. 
bezpieczeństwa publicznego ${ }^{71}$. Równocześnie prawo do życia nie jest prawem, od którego nie ma wyjątków, przy czym jedynie Konwencja praw człowieka i podstawowych wolności wprowadza wyraźny wyjątek dotyczący konfliktu zbrojnego ${ }^{72}$.

W odniesieniu do ukierunkowanych zabójstw Marta Szuniewicz wskazuje, że uderzają one „w dwa fundamentalne prawa człowieka, to jest prawo do życia (a właściwie zakaz arbitralnego pozbawienia życia drugiej osoby) oraz prawo do rzetelnego procesu i wymierzania sprawiedliwości w wyniku kontradyktoryjnego postępowania." ${ }^{73}$. Trafnie wydaje się podsumowywać istniejący stan prawa międzynarodowego w tym zakresie Specjalny Sprawozdawca ds. promowania i ochrony praw człowieka i podstawowych wolności w trakcie zwalczania terroryzmu, który w raporcie z 2013 r. stwierdza: „poza konfliktem zbrojnym użycie śmiercionośnej siły przez państwo jest legalne, tylko jeżeli to ściśle konieczne i proporcjonalne, jeżeli ma na celu zapobieżenie bezpośredniemu zagrożeniu życia oraz jeżeli nie ma innych środków do zapobiegnięcia zagrożeniu przed ziszczeniem. W rezultacie zabójcze ataki zdalnie sterowanych samolotów rzadko będą legalne poza sytuacją konfliktu zbrojnego, ponieważ tylko w najbardziej wyjątkowych okolicznościach, byłoby legalnym w świetle MPPC, aby zabijanie było wyłącznym lub pierwszorzędnym celem operacji"74.

71 Art 4 Międzynarodowego pakt praw obywatelskich i politycznych z 1966 r.; Art. 15 ust. 2 Konwencji o ochronie praw człowieka i podstawowych wolności z 1950 r.; Art. 27 Amerykańskiej konwencji praw człowieka z 1969 r.

${ }^{72}$ Artykuł 15 ust. 2 Konwencji: „Na podstawie powyższego przepisu nie można uchylić zobowiązań wynikających z artykułu 2, z wyjątkiem przypadków śmierci będących wynikiem zgodnych z prawem działań wojennych, oraz zobowiązań zawartych w artykułach 3, 4 (ustęp 1) i 7”.

73 M. Szuniewicz, Dopuszczalność selektywnej eliminacji ws świetle międzynarodowych standardów praw człowieka, «Międzynarodowe Prawo Humanitarne» 4/2013, s. 64-65 i przywołane tam orzecznictwo trybunałów międzynarodowych oraz organów traktatowych zajmujących się ochroną praw człowieka.

74 Emmerson Report, pkt 60; podobnie holenderski Komitet doradczy ds. zagadnień międzynarodowego prawa publicznego: "The deployment of an armed drone in a law enforcement situation will hardly ever constitute a legal use of force. The principle of proportionality as it applies within the human rights regime is considerably stricter 
W tym kontekście można przyjąć, że praktyka ukierunkowanych zabójstw prowadzona za pośrednictwem dronów, poza konfliktem zbrojnym, byłaby niezwykle trudna do obrony tak przed Komitetem Praw Człowieka, jak i przed Europejskim ${ }^{75}$ czy Międzyamerykańskim Trybunałem Praw Człowieka ${ }^{76}$.

\section{ZAKOŃCZENIE}

Problematyka wykorzystania ZBSP wpisuje się w szereg kontrowersji prawnych związanych $\mathrm{z}$ używaniem paradygmatu wojennego w procesie zwalczania międzynarodowego terroryzmu. Wiąże się to z próbą przeniesienia punktu ciężkości z reżimu prawa pokoju (MPPC) na reżim prawa wojny $(\mathrm{MPH}) \mathrm{w}$ rezultacie przekonania, że środki oparte wyłącznie na policyjnej współpracy międzynarodowej są niewystarczające dla skutecznego zwalczania ugrupowań terrorystycznych chroniących się w państwach słabych, ogarniętych wojną domową lub rządzonych przez podmioty je wspierające ${ }^{77}$. W tego rodzaju sytuacjach istnieje dająca się zauważyć tendencja w zakresie praktyki państw do stosowania obok środków o charakterze policyjnym również narzędzi militarnych, zarówno w aspekcie operacyjnym (rodzaj i skala użytej broni), jak i formalnym (powołanie się na prawo do samoobrony i rozwiązania $\mathrm{MPH})^{78}$.

than under IHL, in particular to prevent innocent people falling victim to such attacks", Main conclusions of advice on armed drones, Hague 2013, s. 4; tak również N. Melzer, Targeted Killing..., s. 423; R. Отто, op. cit., s. 110-111.

75 A. Bodnar, I. Pacho, Targeted Killings (Drone strikes) and the European Convention on Human Rights, «Polish Yearbook of International Law» 32/2013, s. 204 i 206.

76 R. Отto, op. cit., s. 130.

77 D. Kretzmer, Targeted Killing of Suspected Terrorists: Extra-Judicial Executions or Legitimate Means of Defence?, «EJIL»16.2/2005, s. 171-212.

${ }_{78}$ Trafnie ujął to H. Koh, wskazując, że „jeżeli Stany Zjednoczone znajdą lidera Al. Kaidy takiego jak Osama bin Laden, w odległej części Afganistanu perspektywa prawa wojennego byłaby bardziej odpowiednia; ale jeżeli zostałby on znaleziony w Londynie lub w Nowym Jorku, model policyjnego egzekwowania prawa byłby oczywiście bardziej adekwatny”, H.H. КоH, op. cit., s. 6; Podobnie Jerzy Menkes prezentuje pogląd, że „uniwersalne normy są kontestowane przez terrorystów i w konsekwencji selektywnej 
Praktyka po zamachach w Paryżu z 13.11.2015 r. uwydatnia, jak wiele prawnych kontrowersji pojawia się w sytuacji, gdy państwa wykorzystują paradygmat samoobrony $\mathrm{i}$ konfliktu zbrojnego w celu zwalczania terroryzmu międzynarodowego. Konsekwencją używania siły w samoobronie jest bowiem sytuacja konfliktu zbrojnego, która zasadniczo zakłada, że obie jego strony (zatem teoretycznie prima facie również Państwo Islamskie (ISIL) oraz Al-Kaida) mogą podejmować działania zbrojne wymierzone w kombatantów drugiej strony. Równocześnie dążenie do zneutralizowania czynnika geograficznego w zakresie konfliktu zbrojnego stawia pytania, czy można uznać, że ma on miejsce na takich samych zasadach np. zarówno we Francji, jak i Syrii ${ }^{79}$.

\section{UżyWANIE DRONÓW W CELU ZWALCZANIA MięDZYNarodowego TERRORYZMU W ŚWIETLE 'IUS IN BELLO'}

\section{Streszczenie}

Wzrastająca praktyka używania zbrojnych bezzałogowych statków powietrznych (ZBSP) w celu eliminacji osób podejrzanych o terroryzm przez niektóre państwa wzbudza szereg kontrowersji w świetle

eliminacji w zupełności nie można wyłączyć jako metody walki z tym zjawiskiem” [...] Państwo jest wyposażone również w oręż prawny: prawo do skutecznej obrony limitowanej tylko zakazem ograniczania praw i wolności człowieka - terrorysty", J. Menkes, O zaletach poprzedzania kwalifikacji prawnej czynów analizą stanów faktycznych - uwag kilka, «Międzynarodowe Prawo Humanitarne» 4/2013, s. 28.

${ }^{79}$ „Można argumentować, że państwa trzecie zaangażowane w ekstraterytorialny niemiędzynarodowy konflikt zbrojny nie powinny mieć możliwości zasłonić się przed zastosowaniem zasady równości beligerentów w świetle MPH od momentu, gdy staną się stroną tego rodzaju konfliktu zbrojnego poza ich granicami (....) zatem, chociaż akty przeprowadzone jako część działań zbrojnych przez stronę niepaństwową na terytorium zaangażowanego państwa będą z pewnością karalne na gruncie prawa krajowego (i najprawdopodobniej kwalifikowalne jako „terroryzm”), mogą one w pewnych okolicznościach być legalne na podstawie MPH. Tak może być w sytuacji, jeżeli atak przez odpowiedni podmiot niepaństwowy został przykładowo skierowany przeciwko celom wojskowym na terytorium interweniującego państwa”, J. PejIC, Extraterritorial targeting by means of armed drones: Some legal implications, "International Review of the Red Cross» 96.893/2014, s. 31. 
istniejących uregulowań prawa międzynarodowego. Artykuł omawia przedmiotową problematykę w pierwszej kolejności z perspektywy ius in bello, tj. międzynarodowego prawa humanitarnego. W tym kontekście przedmiotem analizy jest w szczególności pojęcie niemiędzynarodowego konfliktu zbrojnego, osoby, które mogą być legalnym celem ataków w tego rodzaju konfliktach oraz zakres terytorialny konfliktu zbrojnego. Równocześnie $\mathrm{w}$ artykule przedstawiona została problematyka relacji międzynarodowego prawa humanitarnego i międzynarodowego prawa praw człowieka oraz możliwości zastosowania norm tego ostatniego działu prawa zarówno w kontekście stosowania ZBSP w celu eliminacji osób podejrzanych o terroryzm w konflikcie zbrojnym, jak i poza nim.

\section{The Use of Drones in Combating International Terrorism FROM THE PERSPECTIVE OF IUS IN BELLO}

\section{Summary}

The increasing practice of some states using armed unmanned aerial vehicles (AUAVs) to eliminate persons suspected of terrorism raises a number of controversies regarding its justification under international law. This article discusses these problems in the first place from the perspective of ius in bello i.e. international humanitarian law. In this context I examine the concept of non-international armed conflict, individuals who may be considered a legitimate target of attacks in such conflicts, and the territorial scope of the conflict. I also discuss the relationship of international humanitarian law to international human rights law and the possibility of applying the standards of the latter in the context of the use of AUAVs to eliminate persons suspected of terrorism in and beyond armed conflicts.

Słowa kluczowe: bezzałogowe samoloty latające; konflikt zbrojny; ukierunkowane zabójstwa; prawo do życia.

Key words: drones; armed conflict; targeted killings; right to life. 


\section{Literatura}

AKAnde DAPo, Clearing the Fog of War? The ICRC'S Interpretive Guidance on Direct Participation In Hostilities, «International and Comparative Law Quarterly» 59/2010, s. 180-192

Alston Philipp, Morgan-Foster Jason, Abresch William, The Competence of the UN Human Rights Council and its Special Procedures in relation to Armed Conflicts: Extrajudicial Executions in the 'War on Terror', «EJIL» 19.1/2008, 183-209

Bodnar Adam, Pacho Irmina, Targeted Killings (Drone strikes) and the European Convention on Human Rights, «Polish Yearbook of International Law» 32/2013, s. 189-209

Bucholc Martyna, Użycie bezzałogowych aparatów latających w sytuacji konfliktu zbrojnego. Wybrane aspekty z zakresu międzynarodowego prawa humanitarnego, «Polski Rocznik Praw Człowieka i Prawa Humanitarnego» 3/2012 r., s. 169-182

Corn Geoffrey, Schoettler James, Brenner-Beck Dru, Hansen Victor, Jackson Dick, Jensen Eric Talbot, Lewis Michael W., The War on Terror and the Laws of War: A Military Perspective, Oxford 2015

Dill Janina, The 21st-Century Belligerent's Trilemma, «European Journal of International Law» 26.1/2015, s. 83-108

Goodman Ryan, The Power to Kill or Capture Enemy Combatants, «EJIL» 24.3/2013, s. 819-853

Grzeby Patrycja, Pojęcia „osoba cywilna” oraz „bezpośredni udział w działaniach zbrojnych" (wytyczne Międzynarodowego Komitetu Czerwonego Krzyża), Państwo i Prawo 67.2/2012, s. 60-72

Henckaersts Jean-Marie, Study on customary international law: A contribution to the understanding and respect for the rule of law in armed conflict, «International Review of the Red Cross» 87.857/2005, s. 175-212

KAHN PAUL. W., Imagining Warfare, «European Journal of International Law» 24.1/2013, s. 199-226.

Kranz Jerzy, Między wojna a pokojem: świat współczesny wobec użycia sity zbrojnej, [w:] Świat wspótczesny wobec użycia siły zbrojnej - dylematy prawa i polityki, Warszawa 2009, red. J. KRANZ, s. 81-241

Kretzmer David, Targeted Killing of Suspected Terrorists: Extra-Judicial Executions or Legitimate Means of Defence?, «EJIL» 16.2/2005, s. 171-212 
KuŁAGa Łukasz, Używanie zbrojnych bezzałogowych statków powietrznych $w$ celu zwalczania terroryzmu międzynarodowego świetle 'ius ad bellum', «Zeszyty Prawnicze» 2/2016

Lubell Noam, Derejko Nathan, A global battlefield? Drones and the geographical scope of armed conflict, "Journal of International Criminal Justice» $11.1 / 2013$, s. $65-88$

Melzer Nils, Targeted Killing in International Law, Oxford, 2008

Menkes Jerzy, O zaletach poprzedzania kwalifikacji prawnej czynów analiza stanów faktycznych - uwag kilka, «Międzynarodowe Prawo Humanitarne» 4/2013, s. 12-32

Milanovic MaRCo, Lessons for human rights and humanitarian law in the war on terror: comparing Hamdan and the Israeli Targeted Killings case, «International Review of the Red Cross» 89.866/2007, s. 373-393

Milanovic MArco, A Norm Conflict Perspective on the Relationship between International Humanitarian Law and. Human Rights Law, "Journal of Conflict and Security Law» 14.3/2009, s. 459-483

Mik Cezary, Obowiązywanie i stosowanie traktatów chroniących prawa człowieka w czasie wojny, [w:] 'Fides et bellum' - Księga poświęcona Pamięci Księdza Biskupa, Profesora, Generała, śp. Tadeusza Płoskiego, red. B. Sitek, T. Jasudowicz, M. Seroka, Olsztyn 2012, tom 1, s. 315-369

Mikos-skuza ElżBıeta, Autonomia 'iuris in bello' względem 'ius ad bellum' - wspótczesne wyzwania, [w:] 'Fides et bellum' - Księga poświęcona Pamięci Księdza Biskupa, Profesora, Generała, śp. Tadeusza Płoskiego, red. B. Siтeк, T. Jasudowicz, M. Seroka, Olsztyn 2012, I, s. 395-405

Отто Roland, Targeted Killings and International Law - with Special Regards to Human Rights and International Humanitarian Law, Heidelberg 2012

Parks Hays W., Part IX of the ICRC "Direct Participation in Hostilities" Study: No Mandate, No Expertise, and Legally Incorrect, "Journal International Law and Politics» 42/2010, s. 769-830

Paust J. Jordan, Human rights on the battlefield, «The George Washington International Law Review» 47/2015, s. 509-561

Pejic Jelena, Extraterritorial targeting by means of armed drones: Some legal implications, «International Review of the Red Cross» 96.893/2014, s. 1-40

Reeves Shane R., Bin Laden and Awlaki: Lawful Targets, «Harvard International Review», 26/10 2011, s. 1-4

Sassoli Marco, Olson Laura M., The Relationship Between International Humanitarian Law and Human Rights Law Where it Matters: Admissible 
Killing and Internment of Fighters in Non-International Armed Conflicts, «International Review of the Red Cross» 90.871/2008, s. 599-627

SASSOLI MARCo, Use and Abuse of the Laws of War in the "War on Terrorism", "Law and Inequality: A Journal of Theory \& Practice» 22/2004, s. 195-221

Schmitt Michael N., Wound, Capture, or Kill: A Reply to Ryan Goodman's 'The Power to Kill or Capture Enemy Combatants', «EJIL» 24.3/2013, s. 855-861 SzPak Agnieszka, Bezpośredni udział w działaniach zbrojnych wświetle międzynarodowego prawa humanitarnego, Toruń 2013

Szpak Agnieszka, Selektywna eliminacja $w$ międzynarodowym prawie humanitarnym, «Międzynarodowe Prawo Humanitarne» 4/2013, s. s. 33-44

Szpak Agnieszka, Dopuszczalność pozbawienia życia kombatanta wświetle międzynarodowego prawa humanitarnego, «Polski Rocznik Praw Człowieka i Prawa Humanitarnego» 6/2015, s. 207-227

Szuniewicz Marta, Dopuszczalność selektywnej eliminacji w świetle międzynarodowych standardów praw człowieka, «Międzynarodowe Prawo Humanitarne» 4/2013, s. 45-65

Wagner Markus, The Dehumanization of International Humanitarian Law: Legal, Ethical, and Political Implications of Autonomous Weapon Systems, «Vanderbilt Journal of Transnational Law» 47/2014, s. 1371-1424

Wallace David A, Operation Neptune's Spear: The lawful killing of Osama bin Laden, «Israel Law Review» 45.2/2012, s. 367-377. 